\title{
Assessing the wood sourcing practices of the U.S. industrial wood pellet industry supplying European energy demand
}

\author{
Brian Kittler $^{1 *}$, Inge Stupak ${ }^{2}$ and C. Tattersall Smith ${ }^{3}$
}

\begin{abstract}
Background: As the demand for wood pellets has increased in EU member states, so has a multi-pronged examination of the environmental effects of establishing a transatlantic trade in wood pellets between the U.S. and Europe. However, the nature of industrial wood pellet supply chains is poorly understood or little known. This work aimed to understand the feedstock sourcing strategies being used by the wood pellet industry in the southeast U.S., commonly applied approaches to documenting sustainability of these feedstocks, and drivers operating behind related developments.

Methods: This study used structured interviews of sustainability managers and procurement staff at pellet mills comprising $75 \%$ of the U.S. industrial pellet sector. The industry was classified into types of supply chains, based on the role of loggers, wood dealers, sawmills, and other wood product facilities in the supply chains. Additional classifications examined feedstock types and origins, number and type of suppliers, contractual relationships with suppliers, applied procurement systems, risk assessment and due-diligence methodologies, risk mitigation procedures, and supply chain certifications.
\end{abstract}

Results: Three main types of supply chains were identified within the U.S. industrial pellet sector, differentiated based on features of feedstock procurement, risk assessment procedures, and risk management. The study observed a slight shift toward using a higher proportion of wood residuals as feedstock in some of the larger pellet mills. Policy requirements, customer orders, and external pressures were driving the sector's adoption of sustainability programs, with risk assessments and wood procurement procedures aligned to policy requirements.

Conclusions: The strength of a risk-based approach to sustainability documentation depends on the quality of source data on risks within a sourcing area, scale of analysis, and integration of risk assessments into procurement practices. Some risk categories are more difficult to assess and control. Challenges increase with increasing number and diversity of supply chain actors and depend on the nature of agreements between these entities for the conveyance of feedstocks to pellet mills. Fiber procurement is similar to pulpwood-using industries, but extending the risk assessment to residuals is complicated and challenging to the sector. The study identified a number of strategies in use within pellet mill supply chains for dealing with these challenges.

Keywords: Bioenergy, Biomass, Sustainability standards, Forest certification, Wood pellets, International trade

\footnotetext{
* Correspondence: Bkittler@Americanforests.org

${ }^{1}$ American Forests, Washington, DC, USA

Full list of author information is available at the end of the article
}

(c) The Author(s). 2020 Open Access This article is licensed under a Creative Commons Attribution 4.0 International License, which permits use, sharing, adaptation, distribution and reproduction in any medium or format, as long as you give appropriate credit to the original author(s) and the source, provide a link to the Creative Commons licence, and indicate if changes were made. The images or other third party material in this article are included in the article's Creative Commons licence, unless indicated otherwise in a credit line to the material. If material is not included in the article's Creative Commons licence and your intended use is not permitted by statutory regulation or exceeds the permitted use, you will need to obtain permission directly from the copyright holder. To view a copy of this licence, visit http://creativecommons.org/licenses/by/4.0/. The Creative Commons Public Domain Dedication waiver (http://creativecommons.org/publicdomain/zero/1.0/) applies to the data made available in this article, unless otherwise stated in a credit line to the data. 


\section{Background}

In 2017, half of all renewable energy consumed globally was modern bioenergy ${ }^{1}$ and the share of energy coming from biomass is projected to remain high into the future [1]. Moreover, the Intergovernmental Panel on Climate Change (IPCC) has found significant deployment of negative net emission technologies, including bioenergy carbon capture and storage (BECCS), will be necessary to limit global warming to $2{ }^{\circ} \mathrm{C}$ by 2100 [2-4].

Whether or not such increases are realized, forest bioenergy supply chains are expanding and trade in biomass feedstocks is global. In the last decade, international trade in wood pellets has developed between suppliers in the southeast U.S. and European energy companies and is now the third largest wood product export from the southeast U.S., behind softwood and hardwood lumber, albeit still a minor share $(3 \%)$ of the total export volume of wood products $[5,6]$.

At the foundation of this transatlantic trade is a system of policy targets, such as the European Union (EU) Renewable Energy Directive [7] and EU member state subsidies that facilitate demand for renewables, including biomass displacing coal in thermoelectric power stations [8, 9]. In 2018, European Union demand for wood pellets amounted to approximately 23 million metric tonnes, of which the U.S. supplied $27 \%$ [10]. It is highly likely that wood pellets imported from the southeast U.S. in the next decade will comprise the largest source of biomass other than those generated within the $\mathrm{EU}[8,9,11]$, even if European demands are currently predicted to stagnate [12]. In 2018, the most important buyers of U.S. wood pellets among European Union member were the UK (4.9 million tonnes), Denmark and Belgium (each 0.6 and 0.5 million tonnes), and Italy and the Netherlands (88 and 7 ktonnes, respectively), with the total EU member state imports from the U.S. being 6.1 million tonnes [10]. However, Asian markets are emerging and predicted to account for the largest increase in global bioenergy demand up to 2025 [8]. Canada is currently the main North American exporter to these markets, namely Japan, but the southeast U.S. producers have at least 1.5 million tonnes under contract, with Japan also requiring documentation of sustainability [13]. Existing supply chains in the industrial wood pellet sector of the southeast U.S. offer a glimpse of what further global deployment may look like if significant growth of wood bioenergy occurs.

As demand has increased, so has a multi-pronged examination of the environmental effects of establishing a transatlantic trade in wood pellets [14]. Some environmental nongovernmental organizations (NGOs) argue that

\footnotetext{
${ }^{1}$ Modern bioenergy is the conversion of biomass to heat and electric power using modern technologies vs. traditional bioenergy which involves the open combustion of biomass for heating and cooking.
}

European policies have led to unsustainable wood harvesting outside the EU and question climate change mitigation benefits, in part due to the life cycle accounting for greenhouse gas emissions of biomass feedstocks $[6,15,16]$. Regulatory requirements from individual EU member states and the United Kingdom (UK) and pressure from NGOs on both sides of the Atlantic are influencing the complexion of wood pellet plants' supply chains and biomass sourcing strategies [17]. For instance, pressure from local NGOs led to one company issuing a policy of avoiding biomass from certain forest types [18]. The UK's timber procurement policies require that certain standards are met by UK wood pellet-using industries in order to be eligible for Renewables Obligation Certificates [19], and Belgium [20, 21], Denmark, and the Netherlands also each have their own national requirements associated with obtainment of subsidies $[17,22]$. These two factors were drivers of the creation of the Sustainable Biomass Program (SBP), which is a certification system that uses a risk-based approach to conformance with European national requirements [22]. Another certification program, the Green Gold Label (GGL), specialized particularly in conformance with the Dutch requirements.

The U.S. industrial wood pellet sector is adopting feedstock procurement systems and supply chains to meet customer expectations, while also seeking continued adoption of national or state-level programs (e.g., Master Logger certifications and SFI Fiber Sourcing) that are designed to help wood-using industries comply with national and state-level policies in the U.S. European Union member states, such as UK and Denmark, generally accept risk-based approaches to document sustainability of bioenergy feedstocks [17]. Italy does not have specific sustainability requirements for energy feedstock, probably due to imports mainly being used to supplement domestic production for residential uses $[9,23,24]$. The Dutch requirements of the SDE+ renewable scheme, adopted in 2017, are more complex, among other factors, due to an attempt to link all biomass feedstocks back to specific stands with evidence that a specific forest management unit providing biomass feedstocks was sustainably managed and harvested $[25,26]$. This is one reason that U.S. imports to the Netherlands decreased from 22 ktonnes in 2016 to 6 ktonnes in 2018 [10]. Additionally, it is still uncertain how new EU requirements will be implemented from 2021 onward [27]. Exporting pellet producers must keep up with these developments as new sustainability regulations are added in different countries and jurisdictions, and all of these efforts have yet to create trust among critical NGOs that these supply chains are environmentally sustainable.

Market trends and environmental effects of this growing market have been analyzed at a regional level [14, 28-33], 
but such high level studies leave several questions as to how effectively environmental safeguards can be implemented. The challenges to adopting such practices are also less documented. Such information is only available directly from pellet mills, which represent the major supply of wood biomass from the U.S. that is being used for modern bioenergy in Europe (principally the UK and the Netherlands).

To date, a comprehensive assessment of the specific wood sourcing and sustainability strategies used by the U.S. industrial wood pellet sector at the level of individual supply chains has not been completed. This study fills this gap and expands the body of knowledge and research on forest bioenergy sustainability. Thus, the specific aims of this research were to better understand:

- Feedstock sourcing strategies of the wood pellet industry in the southeast U.S.;

- Sustainability initiatives used for demonstrating compliance with sustainability criteria;

- Drivers of companies' engagement with sustainability initiatives;

- Significant challenges to documentation of compliance with sustainability criteria and areas of potential improvement; and

- Challenges for the industry in communications about sustainability issues with stakeholders.

This research follows on several examinations (e.g., $[14,22,25,28,34-43])$ of how the various sustainability certifications used by the forest bioenergy industry comply with European Union and member state sustainability criteria in the stage of development or after adoption $[17,23]$, augmenting this literature with an in-depth examination of feedstock sourcing procedures in actual supply chains. Our research is relevant to the current policy discourse about the validity of a risk-based approach to sustainability documentation in the bioenergy sector. We examine the contention of Sikkema et al. [34] that for the southeast U.S. reliance on risk-based supply chain, certifications offer "insufficient coverage of sustainable sourcing topics," in light of recent policy decisions by the European Commission that codify a risk-based approach to supply chain sustainability as sufficient in meeting policy objectives of the revised EU Renewable Energy Directive [27].

Based on data gathered through interviews with personnel from industrial wood pellet companies, we document which feedstocks and certification systems are used and how aspects of these systems (i.e., principles, criteria, indicators) relate to the feedstock procurement protocols of the U.S. industrial pellet sector. This research is relevant as an input to further the robustness of the dialogue about the sufficiency of sustainability criteria and the industry implementation of them.

\section{Methods}

Using a structured interview questionnaire (see supplementary materials), 15 telephone interviews were conducted in 2017 with sustainability managers and wood procurement staff from six companies manufacturing industrial wood pellets in the southeast U.S. Interviews spanned 17 pellet mills representing over $75 \%$ of the wood pellet export capacity of the southeast U.S. as of June 2017. A 100\% response rate was achieved in our attempt to survey a representative sample of the industry.

Respondents were selected for interview based on their roles in:

a) Tracking and reporting feedstock sourcing,

b) Procuring feedstock from and maintaining relationships with suppliers, and/or,

c) Communicating results of sourcing practices and sustainability policies to customers and regulators.

The interview questionnaire included 28 main questions with several sub-questions (see supplementary materials). Questions were designed based on knowledge of feedstock sourcing within the wood pellet industry, sustainability programs (e.g., certifications for forest management and chain of custody), and the policies driving bioenergy supply chains. The interview questionnaire was designed to elicit responses related to several research questions, including:

1) What drives the engagement of the pellet sector in sustainability initiatives?

2) What supply chain sustainability governance structures (e.g., certifications) are used by the U.S. industrial pellet sector?

3) Are there common feedstock sourcing strategies and supply chain structures that exist within the pellet sector?

4) What challenges and opportunities face the industry in participating in supply chain certification and sustainable sourcing programs?

A schematic of supply chains and feedstock definitions were used during interviews to elicit clear responses pertaining to the identification of feedstocks used and supply chain structures (see supplementary materials). Defined feedstock types included primary fiber and both secondary and tertiary residuals. Primary residuals are harvest residuals, including tops, limbs, bark, foliage, and other nonmerchantable materials made available for collection during roundwood timber harvests. Secondary residuals are mill residuals and other by-products of wood product operations (sawmills, pulp and paper mills, wood manufacturers, etc.) such as sawdust, wood shavings, and chips. Tertiary residuals are post-consumer wood waste, e.g., construction 
and demolition waste. Roundwood is also a feedstock for industrial pellets; this category can generally be considered non-sawtimber roundwood, or logs not used in sawmills, generally including pulpwood size and assortments, other small-diameter trees from thinning operations, low-priced chip-n-saw-sized logs, and defect logs. Roundwood can be produced at several points during a timber rotation and is the most expensive wood energy feedstock.

Respondents were asked whether they have environmental sustainability policies, and specifically, if they apply systems by the Sustainable Forestry Initiative (SFI), including forest management certification (SFI FM), chain of custody certification (SFI COC), or fiber sourcing (SFI FS); the American Tree Farm System (ATFS); Program on Endorsement of Forest Certification Controlled Sourcing (PEFC CS); Forest Stewardship Council (FSC), including forest management certification (FSC FM), chain of custody certification (FSC COC), and Controlled Wood (FSC CW); and the Sustainable Biomass Program (SBP).

The SBP uses a risk-based approach to verification of low risk that sourced materials are non-compliant with their sustainable forest management standard, and it includes a module to collect information for demonstration of compliance with supply chain greenhouse gas emission saving criteria, with certification taking place at the pellet mill level. FSC CW also uses a risk-based approach to verify low risk that controversial sources are being used and PEFC CS similarly uses a risk-based sourcing protocol albeit not as specific to those criteria identified in FSC CW (e.g., high conservation values, forest conversion, etc.). FSC CW, PEFC CS, and SBP are to some extent overlapping in that all of these systems focus on assessments of supply chain sourcing risks pertaining to various criteria. This is also the case for the EU Timber Regulation [40], which also prescribes a due diligence system to showing low risk of illegal wood being placed on the EU markets, including products based on primary or secondary wood fiber. All respondents exporting to the EU will comply with the regulation, and they were not asked about this in the interview questionnaire.

We refer to systems that require certification or verification of actors downstream in the supply chain as "supply chain certifications," i.e., from mill and downstream to the energy plants, with no certification of forest management units upstream from the mill. These include SFI COC, SFI FS, FSC COC/CW, PEFC COC/CS, and SBP. These systems are required if mixing of material takes place with material that has a forest management certificate, but the material is also sometimes mixed with material that has no forest management certificate. Additionally, respondents were asked to explain any other sourcing or procurement procedures used that incorporate environmental sustainability, e.g., Corporate Social Responsibility programs (CSR), agreements with local environmental nongovernmental organizations about wood sourcing, and/or public disclosure of souring data.

Interviews were recorded and transcribed. Transcripts were coded, and coded data were organized in an MS excel database for qualitative analysis of crosscutting themes and patterns across the pellet mills interviewed. Categories examined include biomass sourcing practices (e.g., use of intermediary parties to aggregate supply), feedstock supply chains (e.g., sourcing of primary and secondary fiber), and sustainability programs used (e.g., forest management and supply chain certifications). The database facilitated a comparison of responses from different respondents within companies and across companies.

As another source of data against which the results of the structured interviews were considered, site visits were conducted at three pellet mills in the southeast U.S. in 2018. Site visits consisted of non-structured interviews (i.e., without inclusion of a standardized interview guide) with pellet mill procurement foresters and staff responsible for reporting on sourcing practices and sustainability programs. Loggers and wood dealers supplying these mills were also interviewed. Data gathered from these site visits were used to confirm and expand upon the information gathered in the telephone interviews conducted in 2017. Based on the initial data gathered in the telephone interviews and in the site visits, supply chains were classified into three types, each consisting of pellet mills exhibiting similar supply chain characteristics, in terms of used feedstock sources, procurement systems, and certifications.

\section{Results}

We first address what drives participation in supply chain certifications and other sustainability programs used by the U.S. industrial pellet sector. Following this is an examination of sustainability programs used and how these both influence and are influenced by feedstock sourcing strategies and the structure of supply chains. Lastly, we report on challenges and opportunities facing pellet mill participation in sustainability sourcing programs.

\section{What drives engagement of the pellet sector in sustainability initiatives?}

Respondents claimed that local, state, federal, and international policies all "govern" these supply chains, specifically influencing how wood is grown and harvested, but that customer requirements dictate supply chain certifications. Respondents suggested that international policies as expressed in customer demands strongly influence both pellet mill sourcing strategy and corporate structure. This is particularly expressed in the use of risk assessments, fiber procurement and tracing technologies, risk 
mitigation tactics, selection of wood dealers, and the structure and responsibilities of procurement staff.

As cited by respondents, the policy drivers of the sustainability governance in their supply chains include:

- State-level policies (e.g., water quality laws),

- Federal, i.e., Clean Water Act [44] and the Endangered Species Act [45], and

- International (e.g., biomass procurement policy of the UK [46] and the Dutch biomass sustainability criteria under the Stimulation of Sustainable Energy Production, SDE+) [26].

In addition to customer demands, external pressures from NGOs influence the shape of the used sustainability initiatives and wood procurement strategies. Some respondents expressed that they are going above and beyond customer requirements by entering into agreements with local environmental NGOs that identify areas off limits to sourcing. Others have made strides to improve the transparency of their sourcing, citing external pressure. Another factor is how companies approach the concept of sustainability and what they wish their corporate culture to be. This includes how companies are structured and staffed, i.e., how many personnel hours are dedicated to sustainability programs, and also how the companies choose to engage NGOs, e.g., whether they consider their concerns legitimate or not.

\section{Which supply chain sustainability governance structures are used by the U.S. industrial pellet sector?}

Pellet mills reported adopting various forms of nongovernmental sustainability governance, in the form of supply chain certifications (Table 1). The most widely used certification programs among mills surveyed are SBP, PEFC COC/CS, SFI COC, SFI FS, and FSC COC/ $\mathrm{CW}^{2}$. The study also identified the pellet industry using six overall strategies in association with their supply chain certifications and wood sourcing procedures, intended for risk assessment and risk management in their supply chains. These strategies often occurred in combination with each other.

1) "Auditing" (by pellet mill staff) of $100 \%$ of secondary feedstock suppliers.

2) "Auditing" a portion (e.g., 10-20\%) of secondary suppliers' supply chains (paper trail audits and/or field audits).

3) Contractually requiring all suppliers to use the FSC $\mathrm{CW}$ and PEFC CS standards with chain of custody

\footnotetext{
${ }^{2}$ Detailed descriptions of certification systems and how they address risks are available in Olesen et al. [14].
}

certifications or that they adhere to the main elements of these standards.

4) Extending spatial risk assessments ${ }^{3}$ to encompass the sourcing area of secondary residual suppliers.

5) Offering to certify the forest management plans of landowners supplying sawmills providing mill residuals to a pellet mill (i.e., group certification managed by the pellet mill). Group certification is used in both FSC and ATFS.

6) Adopting technology that integrates spatial risk assessments and primary fiber sourcing and material tracking procedures.

Accompanying the adoption of these strategies are written environmental sustainability policies related to sourcing practices. All but three pellet mills in this study reported having such documents. Stated reasons for having written sourcing policies included that it is an aspect of workforce training; it helps establish a corporate culture; it communicates corporate values to suppliers, stakeholders, and customers; and it helps demonstrate and ensure regulatory compliance.

Respondents expressed that their adoption of supply chain certifications and sourcing procedures is largely in response to the policy drivers linked to the market. External policies, particularly the policies of countries sourcing wood pellets from the southeast U.S., often make explicit reference to other non-regulatory tools for forest management unit level certification, chain of custody with controlled sources/controlled wood certification, or certification with low risk of non-compliance with forest management standards at the wood pellet producer level. As depicted in Table 1, adoption of many of these systems is common, particularly supply chain certifications like the SBP.

At present, however, for the majority of the industrial wood pellet sector of the southeast U.S., the volume of fiber that can be traced back to a forest certified to a forest management certification standard is low, except for mills that are closely linked with another forest products facility, i.e., a single local sawmill and industrial ownership certified to the SFI forest management standard.

All of the larger pellet mills $(+300,000$ metric tonnes year $^{-1}$ production capacity) using mostly primary fiber as feedstock reported having asked landowners to certify their forest. This is usually done indirectly through their suppliers and/or partner organizations, such as the ATFS, a program geared for engaging non-industrial private forest owners to obtain forest management

\footnotetext{
${ }^{3}$ Within the context of forestry, a spatial risk assessment is a mapping analysis that identifies certain risk categories, e.g., risk of damaging an area rich in biodiversity, within a landscape pertaining to wood sourcing.
} 
Table 1 Certifications used by the 17 sampled industrial pellet mills in the southeast U.S.

\begin{tabular}{|c|c|c|}
\hline $\begin{array}{l}\text { Pellet } \\
\text { mill }\end{array}$ & Forest management certification & Supply chain certification \\
\hline 1 & $\begin{array}{l}15 \% \text { of primary fiber SFI FM; } 30-35 \% \text { of the secondary residuals carry SFI FM certificates, } 5 \% \text { of secondary } \\
\text { residuals carry FSC FM certificates). }\end{array}$ & $\begin{array}{l}\text { SFI FS, SFI COC, PEFC COC, FSC } \\
\text { CW, SBP. }\end{array}$ \\
\hline 2 & $12 \%$ primary fiber certified (10\% SFI FM, $2 \%$ ATFS), no residual sources carry FM certificates. & $\begin{array}{l}\text { SFI FS, SFI COC, PEFC COC, FSC } \\
\text { CW, SBP. }\end{array}$ \\
\hline 3 & $4 \%$ primary fiber certified ( $3 \% \mathrm{SFI}, 1 \%$ ATFS), no residual sources carry FM certificates. & $\begin{array}{l}\text { SFI FS, SFI COC, PEFC COC, FSC } \\
\text { CW, SBP. }\end{array}$ \\
\hline 4 & $\begin{array}{l}4.5 \% \text { primary feedstock certified ( } 4 \% \text { SFI FM, } 0.5 \% \text { ATFS), } 0.01 \% \text { of secondary residuals carry FSC FM } \\
\text { certificates). }\end{array}$ & $\begin{array}{l}\text { SFI FS, SFI COC, PEFC COC, FSC } \\
\text { CW, SBP. }\end{array}$ \\
\hline 5 & $6.1 \%$ primary fiber certified ( $6 \% \mathrm{SFI} F M, 0.1 \%$ ATFS), $0.01 \%$ of secondary residuals carry FSC FM certificates. & $\begin{array}{l}\text { SFI FS, SFI COC, PEFC COC, FSC } \\
\text { CW, SBP. }\end{array}$ \\
\hline 6 & $1 \%$ primary fiber SFI FM, $0.01 \%$ of secondary residuals carry FSC FM certificates). & $\begin{array}{l}\text { SFI FS, SFI COC, PEFC COC, FSC } \\
\text { CW, SBP. }\end{array}$ \\
\hline 7 & $41-51 \%$ primary fiber certified (40-50\% SFI FM, 1\% ATFS). & $\begin{array}{l}\text { PEFC CS, FSC CW, SFI FS, SFI } \\
\text { COC, PEFC COC, SBP. }\end{array}$ \\
\hline 8 & $41-51 \%$ primary fiber certified (40-50\% SFI FM, 1\% ATFS). & $\begin{array}{l}\text { PEFC CS, FSC CW, SFI FS, SFI } \\
\text { COC, PEFC COC, SBP. }\end{array}$ \\
\hline 9 & $41-51 \%$ primary fiber certified (40-50\% SFI FM, 3\% ATFS). & $\begin{array}{l}\text { PEFC CS, FSC CW, SFI FS, SFI } \\
\text { COC, PEFC COC, SBP. }\end{array}$ \\
\hline 10 & SFI FM, ATFS, and FSC FM (mostly sourcing from dual SFI/FSC certified lands). & $\begin{array}{l}\text { SFI COC, FSC CW, SBP certified, } \\
\text { SFI FS. }\end{array}$ \\
\hline 11 & Not sourcing directly from certified forests. & $\begin{array}{l}\text { PEFC COC, PEFC CS; FSC CW, } \\
\text { SBP compliant. }\end{array}$ \\
\hline 12 & Not sourcing primary fiber directly from certified forests, 12\% secondary residual SFI FM. & $\begin{array}{l}\text { PEFC COC, PEFC CS; FSC CW, } \\
\text { SBP compliant. }\end{array}$ \\
\hline 13 & Did not report sourcing directly from certified forests. & $\begin{array}{l}\text { PEFC COC, PEFC CS, FSC CW, } \\
\text { SBP compliant. }\end{array}$ \\
\hline 14 & Did not report sourcing directly from certified forests. & $\begin{array}{l}\text { PEFC COC, PEFC CS, FSC CW, } \\
\text { SBP compliant. }\end{array}$ \\
\hline 15 & Did not report sourcing directly from certified forests. & $\begin{array}{l}\text { PEFC COC, PEFC CS, FSC CW, } \\
\text { SBP compliant. }\end{array}$ \\
\hline 16 & $100 \%$ of feedstock SFI FM. & $\begin{array}{l}\text { FSC CW, PEFC CS, SBP certified, } \\
\text { SFI FS. }\end{array}$ \\
\hline 17 & $28 \%$ of feedstock certified (21\% SFI FM, 7\% ATFS). & $\begin{array}{l}\text { FSC CW, FSC COC, SBP certified, } \\
\text { GGL, SFI FS. }\end{array}$ \\
\hline
\end{tabular}

SFI FM Sustainable Forestry Initiative forest management certification, SFI COC Sustainable Forestry Initiative chain of custody, SFI FS Sustainable Forestry Initiative Fiber Sourcing program, ATFS American Tree Farm System certification, PEFC COC Program for the Endorsement of Forest Certification chain of custody, PEFC CS Program for the Endorsement of Forest Certification controlled sources, FSC FM Forest Stewardship Council forest management certification, FSC COC Forest Stewardship Council chain of custody, FSC CW Forest Stewardship Council controlled wood, SBP certified sustainable biomass program certification, SBP compliant sustainable biomass program compliant biomass, GGL Green Gold Label certification

certification. Two of these companies reported beginning to work with secondary residual supplying sawmills and landowners within their supply chains by offering ATFS group certification services to landowners within the supply base of the sawmills. The pellet mill and sawmill are then able to claim fiber sourced from these lands as certified content. However, smaller pellet mills more reliant on a higher proportion of secondary residuals in their feedstock mix have not adopted such an approach.

A common strategy for dealing with secondary residual feedstock among the pellet mills using a high proportion in their feedstock mix is to expand the geographic extent of their supply chain certification risk assessment to be inclusive of the sourcing areas of their secondary residual suppliers. This is often paired to a sourcing protocol that limits secondary residual suppliers to only those who themselves participate in many of the same supply chain certifications, principally PEFC CS and/or FSC CW.

Are there common feedstock sourcing strategies and supply chain structures that exist within the pellet sector? Pellet mills sampled ranged from just over 85,000-750, 000 metric tonnes annual production capacity, with an average size of 379,500 metric tonnes. Actual annual production may be more or less than the nameplate capacity for a given pellet mill, i.e., the expected annual 
volume of production at full operation based on facility design. Table 2 includes a range of production capacity estimates provided by plant managers. Data from interviews with pellet plant managers coupled with a review of certification reports in the SBP database indicates that in 2017, actual production at two of the three largest pellet mills was at the lower end of the range of annual capacity provided by plant managers, whereas 2017 production at the last one of the three largest pellet mills was at the upper end of its nameplate capacity. In 2019, actual production at one of these three mills had exceeded its nameplate capacity.

Collectively, the 17 mills surveyed are capable of exporting over 6 million metric tonnes of wood pellets annually. Variation existed in terms of the feedstocks used, strategies for procuring these feedstocks, and the structures of their supply chains (Table 2). For example, one pellet mill procured $100 \%$ of its fiber from a single certified industrial forest ${ }^{4}$ landowner as non-sawtimber roundwood and what they termed harvest residuals (e.g., the fraction of a pine tree top that would not normally be utilized by other pulpwood size-using industries). Another pellet mill sourced a large portion of its feedstock as mill residuals from a company-owned sawmill integrated with an industrial forest ownership, which also supplied non-sawtimber roundwood to the pellet mill. In yet another example, an exporter served as an aggregator, sourcing from many smaller pellet mills to equal quantities of the larger exporting pellet mills. The supply network for this exporter thus involved secondary residuals from over 70 wood product facilities located across six states that were sold as feedstock to the smaller pellet mills within its supply network.

As forests in the southeast U.S. are predominantly in private ownership [47], pellet mills included in this study source mainly from private industrial and non-industrial forests (typically family owned), with plantation and naturally regenerated loblolly and slash pine predominating, but with deciduous (hardwood) tree species being a significant feedstock for some mills. Most of the pellet mills studied did not maintain long-term supply contracts with landowners. In a few instances, pellet mills used supply contracts with industrial forest owners during the first few years of start-up.

Interviewees for a few pellet mills described a shift in their feedstock sourcing over time to sourcing more primary fiber from non-industrial forests, and a higher percentage of secondary fiber (wood processing residuals). Respondents described this as a maturation of their

\footnotetext{
${ }^{4}$ In the southeast U.S. industrial forest ownerships are characterized by their large size, corporate ownership structure, e.g., real estate investment trusts or timber investment management organizations, intensive plantation forestry practices, and objectives which tend to favor wood production and profit maximization.
}

supply chain and sourcing practices. Respondents generally described a process of "ramping up" production, beginning by producing smaller volumes of pellets and growing their throughput over the course of 12-24 months. The process necessitated expanding sourcing strategies from a few suppliers to a larger number of non-industrial landowners for primary fiber and a larger number of secondary residual suppliers.

Primary fiber (roundwood and harvest residuals) was typically procured from thinnings and final harvests up to $80-120 \mathrm{~km}$ (50-75 miles) from a pellet mill. Secondary fiber (sawmill residuals and residuals from wood product facilities using sawn wood) is sourced from within this same supply base area, but also often from much greater distances. Primary fiber, principally pulpwood size roundwood as tree-length logs, in-woods chips, and harvest residuals (treetops and limbs), comprised the largest portion of industrial pellet feedstock supply in the southeast U.S. The highest share of this feedstock type was found in the larger (capacity of + 300,000 tonnes year $^{-1}$ ) pellet mills. Many of the larger pellet mills mixed primary fiber with secondary fiber (mainly sawmill residuals) in proportions of approximately $70-100 \%$ primary to $0-30 \%$ secondary, an observation confirmed by others $[28,48]$. Based on data gathered in 2017, an approximate percentage ratio of 80 : 20 primary to secondary fiber was identified as standard practice for much of the total capacity of the U.S. industrial pellet sector.

Yet, follow-up site visits completed a year after initial telephone interviews found that three larger pellet mills (capacity of $+350,000$ tonnes year ${ }^{-1}$ ) were in the process of shifting their procurement models to feature significantly more secondary residuals. Respondents reported doing so principally for economic reasons, due to the presence of mill residuals at a lower cost. A consequence of this was that the wood supply base for these three mills had also changed, expanding to include sawmills and other wood product facilities in more distant geographies than prior. Some respondents noted that a shift to secondary fiber was accompanied by revising their risk assessments, as the geographic breadth of the supply-base grew substantially.

Several pellet mills sourced a considerable amount of their feedstock from independent wood dealers, ranging from only a few to as many as 80 . In some instances, wood dealers operated on volume-based contracts with pellet mills. Wood dealers were often foresters and/or loggers who had operated within the southeast forest industry for several years; most often, these individuals were locally networked with landowners and regional forest product facilities. As main suppliers to several of the pellet mills, wood dealers maintained relationships (contractual or otherwise) with regional sawmills, 
Table 2 Feedstock type and source for 17 pellet mills in the southeast U.S. (2017). Annual production capacity given in metric tonnes year ${ }^{-1}$

\begin{tabular}{|c|c|c|c|c|c|c|}
\hline \multirow{2}{*}{$\begin{array}{l}\text { Pellet } \\
\text { mill }\end{array}$} & \multirow{2}{*}{$\begin{array}{l}\text { Annual } \\
\text { production } \\
\text { capacity }\end{array}$} & \multicolumn{2}{|l|}{ Feedstocks used } & \multicolumn{2}{|l|}{ Primary fiber sources } & \multirow{2}{*}{$\begin{array}{l}\text { Secondary and tertiary fiber } \\
\text { sources }\end{array}$} \\
\hline & & Primary fiber & $\begin{array}{l}\text { Secondary } \\
\text { residuals }\end{array}$ & Forest types & Forest ownership & \\
\hline 1 & $\begin{array}{l}100,000- \\
200,000\end{array}$ & $\begin{array}{l}15 \% \text { primary fiber (in-woods } \\
\text { chips from thinnings) }\end{array}$ & $\begin{array}{l}85 \% \text { secondary } \\
\text { residuals ( } 75 \% \\
\text { sawmill residuals } \\
\text { and } 10 \% \text { non- } \\
\text { sawmill wood } \\
\text { product facilities) }\end{array}$ & $\begin{array}{l}\text { Pine and upland } \\
\text { hardwood }\end{array}$ & $\begin{array}{l}15 \% \text { from a single } \\
\text { industrial owner under } \\
\text { long-term contract; } \\
85 \% \text { non-industrial }\end{array}$ & $\begin{array}{l}\text { Volume-based supply } \\
\text { contracts with a few wood } \\
\text { dealers sourcing from } 40 \\
\text { sawmills and } 15 \text { other wood } \\
\text { product facilities }\end{array}$ \\
\hline 2 & $\begin{array}{l}700,000- \\
800,000\end{array}$ & 70\% primary fiber & $\begin{array}{l}30 \% \text { secondary } \\
\text { residuals (sawmill } \\
\text { residuals) }\end{array}$ & 100\% pine & $\begin{array}{l}80 \% \text { non-industrial, } \\
15 \% \text { industrial, } 5 \% \\
\text { public }\end{array}$ & $\begin{array}{l}\text { Volume-based supply } \\
\text { contracts with approximately } \\
15 \text { wood brokers who each } \\
\text { source from the same } 15-20 \\
\text { sawmills }\end{array}$ \\
\hline 3 & $\begin{array}{l}400,000- \\
500,000\end{array}$ & $\begin{array}{l}100 \% \text { primary fiber }(60 \% \\
\text { pulpwood size roundwood } \\
\text { as tree-length logs and } 40 \% \\
\text { in-woods chips) } 90 \% \text { of } \\
\text { which is from final harvests } \\
\text { and } 10 \% \text { thinnings }\end{array}$ & - & $\begin{array}{l}63 \% \text { pine, } 33 \% \\
\text { pine/hardwood, } 3 \% \\
\text { bottomland } \\
\text { hardwood, } 2 \% \\
\text { upland hardwood }\end{array}$ & $\begin{array}{l}97 \% \text { non-industrial; } \\
3 \% \text { industrial }\end{array}$ & $\begin{array}{l}\text { Volume-based supply } \\
\text { contracts with } 10 \text { wood } \\
\text { dealers }\end{array}$ \\
\hline 4 & $\begin{array}{l}300,000- \\
400,000\end{array}$ & $\begin{array}{l}73 \% \text { primary fiber (in-woods } \\
\text { chips) }\end{array}$ & $\begin{array}{l}27 \% \text { secondary } \\
\text { residuals (sawmill } \\
\text { residuals) }\end{array}$ & $\begin{array}{l}63 \% \text { pine, } 33 \% \\
\text { pine/hardwood, 3\% } \\
\text { bottomland } \\
\text { hardwood, } 2 \% \\
\text { upland hardwood }\end{array}$ & $\begin{array}{l}99 \% \text { non-industrial, } \\
1 \% \text { industrial }\end{array}$ & $\begin{array}{l}\text { Volume-based supply } \\
\text { contracts with } 80 \text { wood } \\
\text { dealers sourcing from } 35 \text { to } \\
40 \text { sawmills }\end{array}$ \\
\hline 5 & $\begin{array}{l}500,000- \\
600,000\end{array}$ & $\begin{array}{l}90 \% \text { primary fiber ( } 60 \% \text { of } \\
\text { total is harvest residuals as } \\
\text { limbs and tops and } 30 \% \text { of } \\
\text { total is pulpwood as tree- } \\
\text { length logs) }\end{array}$ & $\begin{array}{l}10 \% \text { secondary } \\
\text { residues (sawmill } \\
\text { residuals) }\end{array}$ & $\begin{array}{l}7 \% \text { bottomland } \\
\text { hardwood, } 7 \% \text { mill } \\
\text { residues, } 60 \% \\
\text { hardwood/pine, } \\
23 \% \text { pine, } 3 \% \\
\text { upland hardwood }\end{array}$ & $\begin{array}{l}99 \% \text { non-industrial, } \\
1 \% \text { industrial }\end{array}$ & $\begin{array}{l}\text { Volume-based supply } \\
\text { contracts with } 80 \text { wood } \\
\text { dealers sourcing from } 35 \text { to } \\
40 \text { sawmill }\end{array}$ \\
\hline 6 & $\begin{array}{l}500,000- \\
600,000\end{array}$ & $\begin{array}{l}80 \% \text { primary fiber ( } 58 \% \text { of } \\
\text { total is pulpwood size } \\
\text { roundwood as tree-length } \\
\text { logs and } 22 \% \text { of total is in- } \\
\text { woods chips) }\end{array}$ & $\begin{array}{l}20 \% \text { secondary } \\
\text { residuals (sawmill } \\
\text { residuals) }\end{array}$ & $\begin{array}{l}2 \% \text { bottomland } \\
\text { forests, } 3 \% \text { pine/ } \\
\text { hardwood, } 30 \% \\
\text { pine, } 7 \% \text { upland } \\
\text { hardwood }\end{array}$ & $\begin{array}{l}99 \% \text { non-industrial, } \\
1 \% \text { industrial }\end{array}$ & $\begin{array}{l}\text { Volume-based supply } \\
\text { contracts with } 80 \text { wood } \\
\text { dealers sourcing from } 35 \text { to } \\
40 \text { sawmill }\end{array}$ \\
\hline 7 & $\begin{array}{l}400,000- \\
500,000\end{array}$ & $\begin{array}{l}70 \% \text { primary fiber } \\
\text { (pulpwood size roundwood } \\
\text { as tree-length logs), 10\% } \\
\text { harvest residuals }\end{array}$ & $\begin{array}{l}20 \% \text { secondary } \\
\text { residuals (sawmill } \\
\text { residuals) }\end{array}$ & $100 \%$ pine & $\begin{array}{l}50 \% \text { non-industrial, } \\
40 \% \text { industrial, } 10 \% \\
\text { public }\end{array}$ & $\begin{array}{l}40 \% \text { with landowners, } 20- \\
30 \% \text { from wood dealers. The } \\
\text { remainder is from sawmills } \\
\text { and/or in-woods chips }\end{array}$ \\
\hline 8 & $\begin{array}{l}400,000- \\
500,000\end{array}$ & $\begin{array}{l}70 \% \text { primary fiber } \\
\text { (pulpwood size roundwood } \\
\text { as tree-length logs), } 10 \% \\
\text { harvest residuals }\end{array}$ & $\begin{array}{l}20 \% \text { secondary } \\
\text { residuals (sawmill } \\
\text { residuals) }\end{array}$ & 100\% pine & $\begin{array}{l}\text { Non-industrial, } 40 \% \\
\text { industrial, } 10 \% \text { public }\end{array}$ & $\begin{array}{l}40 \% \text { with landowners } 20- \\
30 \% \text { from wood dealers. The } \\
\text { remainder is from sawmills } \\
\text { and/or in-woods chips }\end{array}$ \\
\hline 9 & $\begin{array}{l}400,000- \\
500,000\end{array}$ & $\begin{array}{l}\text { 20\% primary fiber } \\
\text { (pulpwood size roundwood } \\
\text { as tree-length logs) }\end{array}$ & $80 \%$ residuals & $\begin{array}{l}\text { + } 90 \% \text { pine, 10\% } \\
\text { hardwood }\end{array}$ & $\begin{array}{l}85 \% \text { non-industrial, } \\
12 \% \text { industrial, } 3 \% \\
\text { public }\end{array}$ & $100 \%$ from wood dealers \\
\hline 10 & $\begin{array}{l}200,000- \\
300,000\end{array}$ & $\begin{array}{l}\text { Roundwood (respondent } \\
\text { considers roundwood a } \\
\text { residual when it comes from } \\
\text { thinnings), harvest residuals }\end{array}$ & $\begin{array}{l}100 \% \text { secondary } \\
\text { residuals from } \\
\text { wood processing } \\
\text { facilities }\end{array}$ & $\begin{array}{l}\text { Pine and mixed } \\
\text { pine/hardwood }\end{array}$ & $\begin{array}{l}\text { Vertically integrated } \\
\text { sourcing primarily } \\
\text { from company owned } \\
\text { lands, other private } \\
\text { lands, and } \\
\text { occasionally public }\end{array}$ & $\begin{array}{l}\text { Does not source from wood } \\
\text { dealers, primarily because } \\
\text { independent wood dealers } \\
\text { do not have chain of custody }\end{array}$ \\
\hline 11 & $\begin{array}{l}100,000- \\
200,000\end{array}$ & - & $\begin{array}{l}100 \% \text { secondary } \\
\text { residuals from } \\
\text { wood processing } \\
\text { facilities }\end{array}$ & $\begin{array}{l}\text { Pine, upland } \\
\text { hardwood/pine }\end{array}$ & $\begin{array}{l}70 \% \text { non-industrial, } \\
25 \% \text { industrial, } 5 \% \\
\text { public }\end{array}$ & $\begin{array}{l}60 \text { sawmills, } 10 \text { non-sawmill } \\
\text { secondary processors. None } \\
\text { of the supply is under long- } \\
\text { term contracts. }\end{array}$ \\
\hline 12 & $\begin{array}{l}200,000- \\
300,000\end{array}$ & $\begin{array}{l}\text { 50\% primary fiber } \\
\text { (pulpwood size roundwood } \\
\text { as tree-length logs). }\end{array}$ & $\begin{array}{l}50 \% \text { secondary } \\
\text { residuals (sawmill } \\
\text { residuals) }\end{array}$ & $\begin{array}{l}\text { Pine, upland } \\
\text { hardwood/pine }\end{array}$ & $\begin{array}{l}70 \% \text { non-industrial, } \\
25 \% \text { industrial, } 5 \% \\
\text { public }\end{array}$ & $\begin{array}{l}60 \text { sawmills, } 10 \text { non-sawmill } \\
\text { secondary processors. None } \\
\text { of the supply is under long- } \\
\text { term contracts }\end{array}$ \\
\hline
\end{tabular}


Table 2 Feedstock type and source for 17 pellet mills in the southeast U.S. (2017). Annual production capacity given in metric tonnes year ${ }^{-1}$ (Continued)

\begin{tabular}{|c|c|c|c|c|c|c|}
\hline \multirow{2}{*}{$\begin{array}{l}\text { Pellet } \\
\text { mill }\end{array}$} & \multirow{2}{*}{$\begin{array}{l}\text { Annual } \\
\text { production } \\
\text { capacity }\end{array}$} & \multicolumn{2}{|l|}{ Feedstocks used } & \multicolumn{2}{|c|}{ Primary fiber sources } & \multirow{2}{*}{$\begin{array}{l}\text { Secondary and tertiary fiber } \\
\text { sources }\end{array}$} \\
\hline & & Primary fiber & $\begin{array}{l}\text { Secondary } \\
\text { residuals }\end{array}$ & Forest types & Forest ownership & \\
\hline 13 & $\begin{array}{l}100,000- \\
200,000\end{array}$ & - & $\begin{array}{l}100 \% \text { secondary } \\
\text { residuals from } \\
\text { wood processing } \\
\text { facilities }\end{array}$ & $\begin{array}{l}\text { Pine, upland } \\
\text { hardwood/pine }\end{array}$ & $\begin{array}{l}70 \% \text { non-industrial, } \\
25 \% \text { industrial, } 5 \% \\
\text { public }\end{array}$ & $\begin{array}{l}60 \text { sawmills, } 10 \text { non-sawmill } \\
\text { secondary processors. None } \\
\text { of the supply is under long- } \\
\text { term contracts }\end{array}$ \\
\hline 14 & $\begin{array}{l}50,000-100 \\
000\end{array}$ & - & $\begin{array}{l}100 \% \text { secondary } \\
\text { residuals from } \\
\text { wood processing } \\
\text { facilities }\end{array}$ & $\begin{array}{l}\text { Pine, upland } \\
\text { hardwood/pine }\end{array}$ & $\begin{array}{l}70 \% \text { non-industrial, } \\
25 \% \text { industrial, } 5 \% \\
\text { public }\end{array}$ & $\begin{array}{l}\text { Sawmills and non-sawmill } \\
\text { secondary processors from a } \\
\text { multi-state area }\end{array}$ \\
\hline 15 & $\begin{array}{l}100,000- \\
200,000\end{array}$ & - & $\begin{array}{l}100 \% \text { secondary } \\
\text { residuals from } \\
\text { wood processing } \\
\text { facilities }\end{array}$ & $\begin{array}{l}\text { Pine, upland } \\
\text { hardwood/pine }\end{array}$ & $\begin{array}{l}70 \% \text { non-industrial, } \\
25 \% \text { industrial, } 5 \% \\
\text { public }\end{array}$ & $\begin{array}{l}\text { Sawmills and non-sawmill } \\
\text { secondary processors from a } \\
\text { multi-state area }\end{array}$ \\
\hline 16 & $\begin{array}{l}500,000- \\
600,000\end{array}$ & $\begin{array}{l}80 \% \text { pulpwood size } \\
\text { roundwood as tree-length } \\
\text { logs; } 20 \% \text { tree tops from } \\
\text { pine plantations }\end{array}$ & - & 100\% pine & $100 \%$ industrial & $\begin{array}{l}100 \% \text { under contract with a } \\
\text { single landowner }\end{array}$ \\
\hline 17 & $\begin{array}{l}700,000- \\
800,000\end{array}$ & $\begin{array}{l}\text { Primary fiber (pulpwood size } \\
\text { roundwood as tree-length } \\
\text { logs and in-woods chips) }\end{array}$ & $\begin{array}{l}\text { Secondary } \\
\text { residuals (sawmill } \\
\text { residuals) }\end{array}$ & $\begin{array}{l}92 \% \text { pine, } 8 \% \\
\text { hardwood }\end{array}$ & $\begin{array}{l}30 \% \text { industrial, } 70 \% \\
\text { non-industrial }\end{array}$ & $\begin{array}{l}32 \text { sawmills, in-woods chips } \\
\text { from } 3 \text { wood dealers, tree- } \\
\text { length roundwood under } \\
\text { contract with } 3 \text { industrial } \\
\text { landowners, secondary resid- } \\
\text { uals from } 45 \text { wood dealers }\end{array}$ \\
\hline
\end{tabular}

directing wood product residuals to pellet mills and other customers. This meant that some pellet mill supply chains feature a large number of other wood product facilities, principally sawmills, with whom their primary relationship existed through a second party.

For example, one of the larger pellet mills surveyed sourced secondary residuals from over 30 sawmills, inwoods chips from three wood dealers, tree-length pulpwood size roundwood under contract with three industrial landowners, and secondary residuals from 45 wood dealers who themselves had sourced from an estimated 400 landowners. While this pellet mill maintains contracts for tree-length pulpwood size roundwood from large industrial forest owners, they did not maintain contracts with wood dealers.

Another pellet mill, relying largely on primary fiber from their own lands, had chosen not to use wood dealers reportedly because of the difficulty in establishing a chain of custody back to feedstock origin, i.e., the forest. Another company suggested that contracts with wood dealers and sawmills were sufficient to address risks that may be in these second party suppliers' supply chains, even if clear chain of custody back to the parcel cannot be established.

Analysis of supply chain feedstock sourcing, supply chains, and sustainability governance formed the basis for a classification of surveyed pellet mills into three different supply chain types (Table 3 and Fig. S2 in supplementary material).
Most supply chains of pellet mills included in this study are type 1 , being mills of $+300,000$ metric tonnes year $^{-1}$ production capacity and sourcing approximately $70-80 \%$ primary fiber as tree length pulpwood size roundwood or in-woods chips (predominantly southern yellow pine) procured from within 50-75 miles of the pellet mill. The remaining $20-30 \%$ of feedstock being predominantly secondary fiber, mostly sawmill residuals, procured from a larger geography. Type 1 supply chains generally involve relationships with several wood dealers (10-80 individual wood dealers) and sawmills, mirroring supply chains of other pulpwood size roundwood using facilities in the region, such as panel products and pulp and paper mills. These relationships are key links in the supply chain that enable wood dealers to fluidly direct wood to market outlets, responding to price signals and the specifications of wood utilization facilities.

While wood dealers typically had some type of agreement with pellet mills, these suppliers may or may not have contracts with individual landowners and/or sawmills from where they procure feedstock. Often, this depends on whether or not the wood dealer purchases the wood outright or merely conveyed the wood to a pellet mill on behalf of a landowner or sawmill. Other pellet mills report not maintaining formal contracts with wood dealers despite other pellet mills citing such contracts as important evidence underpinning their risk rating under their SBP certification. Primary fiber, including harvest residuals, may also be procured directly from a 
Table 3 Common characteristics of pellet mill wood procurement for three types of supply chains

\begin{tabular}{|c|c|c|c|}
\hline Characteristic & $\begin{array}{l}\text { Type 1-large mills sourcing a large } \\
\text { proportion of feedstocks from } \\
\text { pulpwood size roundwood }\end{array}$ & $\begin{array}{l}\text { Type 2-medium to large mills } \\
\text { linked to a sawmill providing a large } \\
\text { proportion of total feedstock as } \\
\text { secondary residuals }\end{array}$ & $\begin{array}{l}\text { Type 3-smaller mills sourcing } 100 \% \\
\text { of feedstock as secondary residuals }\end{array}$ \\
\hline \multicolumn{4}{|c|}{ Feedstock procurement } \\
\hline $\begin{array}{l}\text { Contracts with large } \\
\text { industrial forest ownerships } \\
\text { for primary sourcing }\end{array}$ & $\begin{array}{l}\text { A small portion (10-20\%) of the } \\
\text { supply }\end{array}$ & $\begin{array}{l}\text { Contracts with large industrial forest } \\
\text { ownerships for a significant ( } 50- \\
100 \% \text { ) portion of the supply of } \\
\text { primary fiber }\end{array}$ & $\begin{array}{l}\text { No contracts with large industrial } \\
\text { forest ownerships }\end{array}$ \\
\hline Reliance on wood dealers & $\begin{array}{l}\text { Significant reliance on wood dealers } \\
\text { to provide primary and secondary } \\
\text { fiber }\end{array}$ & $\begin{array}{l}\text { Insignificant reliance on wood } \\
\text { dealers }\end{array}$ & Significant reliance on wood dealers \\
\hline $\begin{array}{l}\text { Sourcing of secondary } \\
\text { residues }\end{array}$ & $\begin{array}{l}\text { Sourcing secondary fiber from } \\
\text { multiple sawmills and re- } \\
\text { manufacturing facilities }\end{array}$ & $\begin{array}{l}\text { Direct sourcing of secondary residues } \\
\text { from a sawmill either owned by the } \\
\text { same company or by a partner in } \\
\text { joint venture }\end{array}$ & $\begin{array}{l}\text { Supply chain is nearly entirely built } \\
\text { around secondary fiber, sourcing } \\
\text { from several sawmills and other } \\
\text { wood product facilities, from a large } \\
\text { area }\end{array}$ \\
\hline
\end{tabular}

\section{Risk assessment (RA) feature}

Use of external consultants and publicly available data for risk assessment (RA)

Level of integration

Standards used for RA

Coverage

General picture

Avoidance of risk identified in RAs

Sourcing from FM-certified forests

Inspecting a portion of harvest by pellet mill staff

Inspecting via

questionnaires and/or site visits a portion (10-100\%) of residual supplier records and sourcing practices

Use of quota systems limiting the amount of nonFM-certified fiber

Use of independently managed group certification programs

Use of supply volume-based agreements that include feedstock sourcing specifications
RA usually completed by external consultants using publicly available data

Commonly feature RAs directly integrated into procedures of primary fiber procurement and indirectly integrated into secondary fiber procurement

RA is done to standards of PEFC CS, FSC CW, and SBP

RAs cover area from where primary fiber is sourced and attempt to cover sourcing area for other suppliers (i.e. sawmills providing secondary fiber)

\section{Risk mitigation}

Considerable variation among mills, use of several measures

Yes, for primary fiber

Yes, for primary fiber. Sourcing mainly from certified industrial forests vs. uncertified non-industrial forests

Yes, for primary fiber

Yes mainly from certified industrial forests vs. uncertified non-industrial forests

Yes, for primary fiber

Yes

Yes, for primary fiber. Use of quota

system to encourage fiber from certified forests

Yes. Including offering to certify the landowners supplying roundwood to sawmills providing pellet mill residuals

Yes, for primary fiber. Some instances where contracts with sawmills are cited as evidence of risk mitigation
Yes. Including offering to certify the landowners supplying roundwood to sawmills providing pellet mills residuals

Yes, for primary fiber. Some instances where contracts with sawmills are cited as evidence of risk mitigation
Comprehensive use of risk mitigation through certification

Yes, for primary fiber

Yes, for primary fiber. Sourcing

RA usually completed by external ticly available Commonly feature RAs directly integrated into primary fiber

RA is done to standards of PEFC CS, RAs cover area from where primary fiber is sourced and attempt to cover sourcing area for other suppliers (i.e., sourcing area for other suppliers (i.e

RA usually completed by external consultants using publicly available data.

$-$

RA is done to standards of PEFC CS, FSC CW, and SBP

RAs attempt to cover sourcing area for all suppliers (i.e., sawmills providing secondary fiber)

Limited risk mitigation

RAs encompass geographic area of secondary residual suppliers or RAs not conducted

Very limited sourcing of primary fiber 
Table 3 Common characteristics of pellet mill wood procurement for three types of supply chains (Continued)

\begin{tabular}{llll}
\hline Characteristic & $\begin{array}{l}\text { Type 1-large mills sourcing a large } \\
\text { proportion of feedstocks from } \\
\text { pulpwood size roundwood }\end{array}$ & $\begin{array}{l}\text { Type 2-medium to large mills } \\
\text { linked to a sawmill providing a large } \\
\text { proportion of total feedstock as } \\
\text { secondary residuals }\end{array}$ & $\begin{array}{l}\text { Type 3-smaller mills sourcing 100\% } \\
\text { of feedstock as secondary residuals }\end{array}$ \\
\hline $\begin{array}{l}\text { CoC, including PEFC CS and } \\
\text { FSC CW }\end{array}$ & Yes, for primary fiber & Yes, for primary fiber & $\begin{array}{l}\text { One company with a number of } \\
\text { pellet mills of supply chain type 3 } \\
\text { reportedly requires that suppliers of } \\
\text { secondary fiber use PEFC CS and FSC } \\
\text { CW certifications }\end{array}$ \\
RA with suppliers & $\begin{array}{l}\text { Yes, for primary fiber. RAs with } \\
\text { suppliers (e.g., wood dealers and } \\
\text { wood residual suppliers) }\end{array}$ & $\begin{array}{l}\text { Yes, for primary fiber. RAs with } \\
\text { suppliers (e.g., wood dealers and }\end{array}$ & $\begin{array}{l}\text { Yes, some companies extend their } \\
\text { RAs to the supply-base of all residual } \\
\text { wood residual suppliers) }\end{array}$ \\
Yse of trained loggers & Yes, for primary fiber & Yes, for primary fiber & - \\
\hline
\end{tabular}

landowner via a logger without a wood dealer being involved. Among the 10 pellet mills classified as type 1 supply chains, secondary fiber was identified as being procured from as few as 15 to as many as 45 sawmills and other wood product facilities, with most of these pellet mills sourcing from more than 30 sawmills.

Some type 1 pellet mills maintained volume-based contracts with the wood dealers supplying them. These contracts may specify some procurement guidelines related to sustainability, such as targets for forest management-certified fiber, but often, pellet mill wood procurement staff work out such specifications with their suppliers on an ongoing basis. For instance, one company reported using a quota system with their suppliers, whereby a maximum of non-certified fiber could be sold to the pellet mill in any given month. Note that both FSC and PEFC require certain procedures for mixing fiber sourced from a certified forest with fiber sourced from a non-certified forest ${ }^{5}$.

A second category of industrial pellet mills, type 2, included those mills that were closely linked with another forest products facility, i.e., a single local sawmill. This type of supply chain is more common for smaller pellet mills. Among type 2 mills surveyed is a nearly vertically integrated company, now a rarity in the U.S. forest products sector, with a pellet mill integrated with a sawmill owned by the same company that also owns certified forestland supplying both mills. Two pellet mills surveyed featured this type of supply chain. A third pellet mill, categorized as type 1 , likely could be considered a type 2 supply chain after the construction of a sawmill adjacent to the pellet mill by a separate company is completed. The pellet mills classified as supply chain type 2 featured very significant use of feedstock from forest management-certified forests.

Pellet mills featuring supply chain type 3 are typically smaller (e.g., 50,000-200,000 metric tonnes year $^{-1}$

\footnotetext{
${ }^{5}$ Strauss [12] provide a thorough review of procedures for mixing certified and non-certified content.
}

production capacity) than type 1 and 2 . Some of these mills were in operation prior to the industrial wood pellet export market existing and reflect the supply chains of most pellet mills in the U.S. that service the residential wood heat market. Type 3 supply chains analyzed for this study aggregated wood pellets at a central location prior to shipment to a port.

\section{What challenges and opportunities face the industry participating in supply chain certification and sustainability sourcing programs?}

The greatest challenge for pellet mills is to increase secondary residual feedstock suppliers' acceptance of, and active participation in, sustainability programs. Strategies for dealing with this vary but include:

- Extending spatial risk assessments to encompass the sourcing area of secondary residual suppliers, typically expanding the spatial risk assessment well beyond the region where primary fiber is sourced,

- Auditing secondary residual suppliers,

- Contractually requiring all suppliers be FSC CW and PEFC CS certified or that suppliers will abide by these standards, and

- Offering to certify the forest management plans of landowners supplying the sawmills (i.e., group certification).

All companies surveyed reported relying on data from secondary and tertiary residual suppliers coupled with an extension of geospatial risk assessments to encompass the supply base of each secondary residual supplier. Risk assessments (for all fiber types) were typically completed to the standards of PEFC CS and FSC CW. These assessments routinely use geospatial datasets developed by a third party for identification of ecological attributes (e.g., known occurrences of rare plants, animals, and ecological communities) posing environmental risks within the potentially available supply area for primary fiber. 
Private consultants completed these spatial risk assessments at the regional or state level (i.e., an area larger than a facility's supply area) to be inclusive of all regions from which the pellet mill might source primary and secondary fiber. Sources of data used in risk assessments generally include NatureServe [49], state Natural Heritage datasets [50], FSC's US national risk assessment ${ }^{6}$ [51], vegetation cover types, and other spatial datasets.

Many (but not all) of the hundreds of sawmills within southeast U.S. industrial pellet mill supply networks participate in supply chain certifications themselves. Respondents reported seeking out such suppliers. The smaller type 3 pellet mills reported that all of their suppliers of secondary and tertiary feedstock carry PEFC CS and FSC CW certificates, which helps confirm district of origin and that risks have been identified and avoided and/or controlled (i.e., mitigated risk and/or feedstocks avoided). Yet, procurement staff from some of the very large type 1 pellet mills reported encountering resistance when asking their secondary residual suppliers to provide feedstock origin data and/or upon urging them to adopt supply chain certification (PEFC CS and FSC CW) if they had not already done so.

Respondents reported visiting a statistically representative sample of secondary and tertiary feedstock suppliers each year (Table 3). This can be a time-consuming activity given the complexity of supply chains, for example, a 200,000-metric tonnes year ${ }^{-1}$ production capacity pellet mill sources from around 60 sawmills and 10 other secondary manufacturing facilities from across a six-state region with supplier contracts requiring BMP compliance and auditing, as well as the use of FSC CW and COC, and PEFC CS and COC.

This involves interviewing suppliers, reviewing supplier data files, and in some instances inspecting a segment of harvests to verify BMPs were used and that controversial sources avoided (as required by PEFC CS and FSC CW). This task is reported to occupy a pellet mill's procurement forester up to 4 weeks per year, in an instance where $100 \%$ of secondary residual suppliers are visited. Across all supply chain types, pellet mills typically invested 1-4 full-time employees to manage due diligence in procurement, including the various sourcing certifications and procedures used.

In addition to first party audits of suppliers, companies reported adapting or developing a series of data management systems to comply with supply chain certifications' due diligence requirements. These databases are

\footnotetext{
${ }^{6}$ Note that at the time of this study, the FSC Controlled Wood National Risk Assessment was still in draft form. Pellet mills wishing to use the FSC Controlled Wood Standard will need to integrate FSC's final Controlled Wood National Risk Assessment into their sourcing and SBP certifications by October 05, 2019. This is likely to be a substantial data source for SBP risk assessments going forward.
}

integrated within the broader sourcing programs of pellet mills. Some respondents reported using global positioning systems (GPS) with timber load ticketing to georeference the coordinates of fiber origin and monitor the flow of fiber at the facility gate. This mechanism is used to establish and maintain chain of custody (COC) back to harvest units from which primary fiber is obtained. Thus, the due diligence system encompasses the initial risk assessment which is subsequently linked to sourcing protocols intended to reduce sourcing from undesirable areas.

Additionally, one company explained that their policy is to only accept a truckload if the load ticket is present at time of delivery and if the origin is known. At least three companies (all type 1 and 2 supply chains) use this approach in conjunction with geographic information system (GIS) mapped risk assessments, identifying areas of potential risk and procurement due diligence procedures $^{7}$, in an attempt to verify the avoidance of areas of high conservation value. For instance, when a wood dealer approaches the procurement forester about a new harvest, the location of the harvest is cross-referenced to the pellet mills GIS-based risk analysis. Depending on the results, a procurement forester may visit the location of the proposed harvest if a risk is detected. These same spatial datasets and supply data management systems are used in monitoring of compliance with water quality best management practices (BMPs). For facilities using PEFC CS and FSC CW, it was common for procurement and/or sustainability personnel to inspect a percentage of harvests annually to ensure that water quality BMPs are used, and, in the case of FSC, that conversion to other land uses has not occurred.

Several of the pellet mills of supply chain type 1 used both procurement foresters and sustainability managers, whose jobs are supported by, and revolve around, such risk assessment and data management systems. Procurement foresters were mainly responsible for working directly and regularly with suppliers for acquisition of feedstock. Sustainability staff monitors this process, complete risk assessments, coordinate first party and third party audits, and gather and evaluate sourcing data for compliance with certification programs. The relationship between procurement and sustainability personnel is described as having a beneficial tension to improve sourcing practices.

\section{Discussion}

This work aimed to document feedstock-sourcing strategies of the wood pellet industry in the southeast U.S. as

\footnotetext{
${ }^{7}$ Due diligence procedures refer to an analysis of wood sourcing practices and their ability to avoid and/or manage risks identified in a risk assessment.
} 
these supply chains are poorly understood. Our research identified commonly applied approaches to documenting conformance to sustainability requirements and challenges to assessing risks within supply chains.

Sikkema et al. [34] concluded that for the southeast U.S., reliance on risk-based supply chain certifications (e.g., PEFC CS/COC and FSC CW/COC) offers "insufficient coverage of sustainable sourcing topics." However, risk-based approaches are accepted by larger wood pellet importing countries in the EU, such as the UK and Denmark [17], and recent policy decisions by the European Commission have also determined such systems to be sufficient in meeting policy objectives of the revised Renewable Energy Directive [27] and, earlier, the EU Timber Regulation [52]. This research has detected variation in the structure of supply chains and the risk assessment and mitigation techniques employed by the U.S. industrial wood pellet sector. In some instances, practices to control risks are more extensive than for other segments of the southeast U.S. wood products industry.

Still, based on the structure of their supply chains and their wood sourcing strategies, some pellet mills face challenges to effectively implementing a risk-based approach. Due to the complexities inherent in sourcing secondary fiber, the pellet sector is challenged by the need for a relatively high degree of due diligence on sourcing a low-value product. Significant time is required to ensure data quality and educate wood dealers and suppliers about the importance of using risk-based systems in landscapes harboring significant biodiversity values and associated risks from forestry activities.

Recognizing that risks are manifested differently in the various supply chain structures, it follows that another important factor influencing the strength of the risk assessment is the type of risk being considered. Some risk categories are more difficult to assess and mitigate than others. For instance, one company using FSC Controlled Wood and its prohibitions on sourcing "conversion wood" acknowledged that upon inspecting for conversion, they did identify that the wood they had sourced came from a forest that had been converted to nonforest land use. A risk assessment consultant interviewed also indicated knowledge of this happening in other instances and that this risk category is particularly challenging to assess and mitigate in the southeast U.S. given market effects, urban development (the largest driver of land-use conversion), cultural influences, and regional land use regulatory context.

At the industrial scale, wood sourcing for pellet mills in the southeast U.S. has generally revolved largely around non-sawtimber roundwood. This study confirms the findings of others $[14,28,53-58]$, that primary fiber, principally pulpwood-sized roundwood as tree-length logs, in-woods chips, and harvest residuals (treetops and limbs), comprises the largest portion of industrial wood pellet feedstock supply in the southeast U.S. This category is more accurately described as fuelwood due to its end use, rather than pulpwood as colloquially used within the southeast forestry sector. The forest economy in the Coastal Plain, the region where most of these pellet mills are located, revolves around markets for pine pulpwood-sized roundwood and pine sawtimber.

Forest management, logging systems, and procurement networks are well established for pulpwood-sized roundwood and have been extended to industrial-scale wood pellets for the export market. While not a rule, we found that the 80:20 ratio between pulpwood-sized roundwood and secondary residuals is fairly common across the industrial pellet sector. This is particularly evident in type 1 and 2 supply chains which comprise most of the southeast U.S. industrial wood pellet capacity.

Procurement systems from the pulp and paper industry have been adapted to wood pellets, and for primary fiber, this generally includes an ability to trace material back to its origin using systems developed by other segments of the wood products industry, and wide use of FSC CW/COC, PEFC CS/COC, and SFI FM with SFI COC. Similar to pellet procurement supply chains, primary fiber procurement for other pulpwood size roundwood-using industries is generally limited to actors (landowners, wood dealers) within the immediate 5075-mile haul distance. The sourcing distance may expand considerably for secondary residuals.

As the industry has grown, feedstock sourcing in the southeast U.S. and the U.S. generally appears to prefer mill residuals (see supplementary materials, Fig. S1), for feedstock quality and economic purposes. Wood residuals have become less expensive for a variety of reasons, such as tightening non-sawtimber pulpwood markets in some locations, and more residues being available due to a recovery of the U.S. housing market and high sawtimber prices. While wood product residuals offer improvements in the greenhouse gas lifecycle performance of forest bioenergy [32, 53], these supply chains are more complex, involving more actors across a wider geography, and thus potentially more risk exposure with regards to areas of high conservation value and forest type conversion. This study provides important insights into how the industry is assessing and managing risk (Table 3). It should also be noted that demand for sawmill residuals by pellet mills is in itself not the driver of forest harvesting decisions.

Forest management certification plays a relatively small role and only in type 1 and 2 pellet mills, with efforts to increase certification only having had marginal success. Seven type 1 pellet mills are attempting to help smaller landowners get certified through independently managed group certifications via ATFS and FSC. One company uses a quota system to encourage additional 
suppliers to certify their forestland or the lands from which they source. This approach has reportedly increased the amount of acres certified. It was deemed by respondents to be impractical for the smaller pellet mills of type 3 with supply chains built around mill residuals to push forest management certification as these pellet mills do not maintain a direct connection to the land.

In general, low-value wood feedstock-dependent industries in the southeast U.S. usually maintain 10-20\% of their supply under long-term contracts with wood dealers or large landowners [53]. This is also the case for industrial wood pellets. Few pellet mills have long-term contracts with residual suppliers and instead look to source from sawmills that have completed analysis of feedstock origin via PEFC and/or FSC, while others do not. This study revealed several examples of pellet mill procurement staff and sustainability personnel citing instances where contracts with suppliers (wood dealers and residual suppliers) allow them to insert language on sustainability requirements which include provisions to allow auditing of secondary residual suppliers. Some pellet mills reported auditing the district of origin for their secondary residual suppliers according to the policies of PEFC and FSC. This process can be quite complex or relatively simple.

\section{Conclusion}

International policies and voluntary certification programs are supporting the use of spatial risk assessment and risk management tools, such as supply chain audits, as the preeminent means of addressing the sustainability of feedstocks in the industrial wood pellet sector of the southeast U.S. This study revealed that there is considerable variation in the supply chains and feedstock procurement strategies within this industry. As such, the adoption of risk assessment and risk management has taken numerous forms.

Assessing the sourcing practices of more than $75 \%$ of the industrial wood pellet production capacity of the southeast U.S., we identified three types of supply chains operating within the wood pellet industry. Each type has nuanced differences in feedstocks used and how they are procured, risk assessment features, and risk mitigation procedures.

While the structure of supply chains themselves may alleviate or elevate risks associated based on the nature of supply linkages in the chain, we found the strength of risk assessments as a mechanism for controlling supply chain risks across all supply chain classifications depended on the following:

1) The quality of sourcing data (do they adequately represent the known and unknown risks?),

2) Appropriateness of the scale and scope of analysis when sourcing areas change (when do new suppliers' risk-based assessment and procurement processes adequately adjust?), and

3) The successful integration of risk assessments and especially mitigation measures into procurement practices.

Another important factor influencing the strength of the risk assessment is the type of risk being considered, such as risk of non-compliance with regulations, risks of sourcing from areas of high biodiversity, or risk of sourcing "conversion wood" from parcels undergoing direct land-use change. Some of these risk categories are more difficult to assess and mitigate than others.

The strength of the risk-based approach is also affected by the scope of risk assessment and management, which in turn depends largely on the type of supply chain. For example, assessing the risk of a supply chain built around a small number of landowners practicing plantation management is relatively straight forward, while risk assessments of supply chains with large numbers of secondary residual suppliers are more complex. The number and diversity of supply chain actors (wood dealers, sawmills, landowners) and the nature of agreements (ranging from handshake deals to legally enforceable contracts) between these actors and pellet mills are all important factors in determining the riskiness of a supply chain. Existing certification systems attempt, in part, to address this through chain of custody certifications, but challenges remain.

Comprising the majority of the export pellet capacity of the southeast U.S., pellet mills of supply chain type 1 are typically very large and source mainly tree-length pulpwood size roundwood and mill residuals. Among the 10 pellet mills in this study classified as type 1, most sourced sawmill residuals from over 30 different sawmills and a majority of primary feedstock came from private non-industrial forests not certified to a forest management certification standard. Type 1 mills rely heavily on intermediary wood dealers for supplying the large volumes of primary and secondary fiber sourced by these very large facilities. In these instances, the primary relationship with landowners and residual suppliers may be several steps removed from feedstock procurement staff working at the pellet mill. Reliance on wood dealers, while widespread, is also recognized as presenting challenges. In fact, respondents from all pellet mills identified their greatest challenge with regard to sourcing as being documenting chain of custody and/or risks from secondary residual suppliers. Respondents suggested that it is timeconsuming and technically complex, if not impossible, to trace feedstock origin back to the forest.

The few pellet mills in this study classified as type 2 rely significantly less on wood dealers than type 1 mills because a majority of feedstock is sourced from a directly linked sawmill. Type 2 pellet mills had a higher use 
of feedstock certified to a forest management certification standard originating from a certified forest. Certified generally because of the influence of other forest product markets, these lands also provide pellet mills with tree-length non-sawtimber roundwood. Type 2 pellet mills in this study used wood dealers sparingly because it was not necessary to meet supply needs and because of challenges establishing chain of custody. A few pellet mills classified as type 3 resemble the operations of pellet mills that existed prior to the export market, and as such, they are significantly smaller. Type 3 mills are also $100 \%$ reliant on mill residuals from a large number of sawmills across a wide geography.

Extending the risk assessment to suppliers of secondary residuals has proven more problematic than extending risk management and mitigation tools used for primary fiber. This is especially critical for pellet mills choosing to increase the proportion of secondary residuals for economic or other reasons. Consultants working with these pellet mills also identify the integration of secondary residual suppliers into risk assessments as presenting unique challenges. This issue is unlikely to be resolved any time soon as the forest economy of the southeast U.S. is free flowing and the value of forest biomass is low. Thus, investments in solving this problem are unlikely to occur without policy drivers.

Still, companies are instituting risk mitigation strategies for their sourcing challenges. Strategies we observed in this study include first party auditing (by pellet mill staff) of secondary residual suppliers' supply chains, requiring all suppliers to use the FSC CW and PEFC CS standards, and offering to enroll in group certification the landowners supplying sawmills within a pellet mill's sourcing network.

Lastly, technology is also recognized as offering possible solutions toward improving the approach to risk assessment and mitigation of all supply chain types. For instance, some pellet mills have integrated spatial datasets used in risk assessment with due diligence procedures performed to verify risks associated with individual loads of primary fiber. Likewise, such datasets could be integrated with remote sensing data for monitoring purposes. While technology for tracking flows of primary fiber has evolved and is being used for pellets, such solutions have yet to be applied across the diversity of supply chain actors and feedstocks presently involved in the industrial wood pellet economy.

\section{Supplementary information}

Supplementary information accompanies this paper at https://doi.org/10. 1186/s13705-020-00255-4.

Additional file 1: Supplementary materials: Structured interview questionnaire.

\section{Abbreviations}

ATFS: American Tree Farm System; BECCS: Bioenergy carbon capture and storage; BMP: Best management practice; COC: Chain of custody; CSR: Corporate Social Responsibility; EU: European Union; EUTR: European Union Timber Regulation; FSC: Forest Stewardship Council; FSC FM: Forest Stewardship Council forest management certification; FSC COC: Forest Stewardship Council chain of custody certification; FSC CW: Forest Stewardship Council controlled wood; GIS: Geographic information system; GPS: Global positioning system; IEA: International Energy Agency; IPCC: Intergovernmental Panel on Climate Change; NGO: Non-governmental organization; PEFC: Program on Endorsement of Forest Certification; PEFC CS: Program on Endorsement of Forest Certification Controlled Sources; RA: Risk assessment; SDE +: The Netherland's stimulation of energy production policies; SFI: Sustainable Forestry Initiative; SFI FM: Sustainable Forestry Initiative Forest Management Certification; SFI COC: Sustainable Forestry Initiative chain of custody certification; SFI FS: Sustainable Forestry Initiative fiber sourcing program; SBP: Sustainable Biomass Program;

UK: United Kingdom; U.S.: United States of America

\section{Acknowledgements}

This research was completed as part of the International Energy Agency (IEA) Bioenergy research project "Measuring, governing and gaining support for sustainable bioenergy supply chains (IEA Bioenergy" aimed, among other, at making recommendations for improving the legitimacy and effectiveness of supply chain governance systems for sustainability. The views expressed are those of the authors and do not necessarily reflect the views or policies of IEA Bioenergy.

\section{Authors' contributions}

Brian Kittler was the Principal Investigator for this study and was responsible for study planning and execution and writing of the paper. Inge Stupak and C. Tattersall Smith contributed to the study design, critical review of results and their presentation, background knowledge, and context. The authors read and approved the final manuscript.

\section{Funding}

This research was funded by the International Energy Agency (IEA) Bioenergy, under the research project "Measuring, governing and gaining support for sustainable bioenergy supply chains," and by the Pinchot Institute for Conservation.

\section{Availability of data and materials}

References have been provided within the "Methods" section for all data used to develop this manuscript. All data are available from publicly accessible sources and have been referenced. Data sharing is therefore not applicable to this article. Please contact authors for any information on data sources or for actual data.

Ethics approval and consent to participate

Not applicable.

\section{Consent for publication}

Not applicable.

\section{Competing interests}

None of the authors have any competing interests in the manuscript.

\section{Author details}

${ }^{1}$ American Forests, Washington, DC, USA. ${ }^{2}$ University of Copenhagen, Copenhagen, Denmark. ${ }^{3}$ University of Toronto, Toronto, Canada.

Received: 6 March 2019 Accepted: 22 April 2020

Published online: 26 May 2020

\section{References}

1. IEA (2018) Renewables 2018: analysis and forecasts to 2023. International Energy Agency. https://webstore.iea.org/download/summary/2312 ?fileName=English-Renewables-2018-ES.pdf. Accessed 8 Jan 2020.

2. IPCC (2014) Intergovernmental Panel on Climate Change 2014 Climate change 2014: mitigation of climate change Contribution of Working. 
https://www.ipcc.ch/site/assets/uploads/2018/02/ipcc_wg3_ar5_full.pdf. Accessed 8 Jan 2020.

3. Jonker JGG, van der Hilst F, Markewitz D, Faaij APC, Junginger HM (2018) Carbon balance and economic performance of pine plantations for bioenergy production in the Southeastern United States. Biomass and Bioenergy 117:44-55. https://doi.org/10.1016/j.biombioe.2018.06.017

4. Mattews R, Hogan G, Mackie E (2018) Carbon impacts of biomass consumed in the EU: supplementary analysis and interpretation for the European Climate Foundation. Available at: https://europeanclimate.org/wpcontent/uploads/2018/05/CIB-Summary-report-for-ECF-v10.5-May-20181.pdf. Accessed 8 Jan 2020.

5. Goetzl A (2015) Developments in the global trade of wood pellets. U.S. International Trade Commission. Office of Industries Working Paper. No. ID039, pp 26.

6. Dale VH, Kline KL, Parish ES, Cowie AL, Emory L, Malmsheimer RW, Slade R, Smith CT, Wigley TB, Bentsen NS, Berndes G, Bernier P, Brandão M, Chum H, Diaz-Chavez R, Egnell G, Gustavsson L, Schweinle J, Stupak I, Trianosky P, Walter A, Whittaker C, Brown M, Chescheir G, Dimitriou I, Donnison C, Goss Eng A, Hoyt KP, Jenkins JC, Johnson K, Levesque CA, Lockhart V, Negri MC, Nettles JE, Wellisch M (2017) Status and prospects for renewable energy using wood pellets from the southeastern United States. GCB Bioenergy 9: 1296-1305. https://doi.org/10.1111/gcbb.12445. Accessed 8 Jan 2020.

7. Directive $2009 / 28 / E C$ of the European Parliament and of the Council of 23 April 2009 on the promotion of the use of energy from renewable sources and amending and subsequently repealing Directives 2001/77/EC and 2003/30/EC. https://eur-lex.europa.eu/legal-content/DA/ALL/?uri=CELEX\%3 A32009L0028. Accessed 8 Jan 2020.

8. Future Metrics (2018) Pellet markets soar in 2018 - a year-end review and outlook. https://www.futuremetrics.info/wp-content/uploads/2018/12/ FutureMetrics\%20White\%20Paper\%20-\%20Review\%20and\%20Global\%2 0Outlook\%20for\%20the\%20Wood\%20Pellet\%20Markets\%20-\%2 ODecember\%202018.pdf. Accessed 5 Feb 2019.

9. Thrän D, Schaubach K, Peetz D, Junginger M, Mai-Moulin T, Schipfer F, Olsson O, Lamers P. (2018) The dynamics of the global wood pellet markets and trade-key regions, developments and impact factors. Biofuels, Bioproducts and Biorefining 3:267-280. https://doi.org/10.1002/bbb.1910,

10. Eurostat (2019). Data on EU pellet imports from the U.S. in 2016 - 2019. https://ec.europa.eu/eurostat. Accessed 8 Jan 2020.

11. Lamers P, Junginger M, Dymond CC, Faaij A (2014) Damaged forests provide an opportunity to mitigate climate change. GCB Bioenergy 6:44-60 https://doi.org/10.1111/gcbb.12055

12. Strauss W. Global pellet market outlook in 2017. https://www.pellet.org/ wpac-news/global-pellet-market-outlook-in-2017. Accessed 1 Mar 2019.

13. Parton S (2019) Japanese demand for wood pellets largely fulfilled by North American producers. Forest2Markets, March 12, 2019. https://www.forest2 market.com/blog/japanese-demand-for-wood-pellets-largely-fulfilled-bynorth-american-producers.

14. Olesen AS, Bager SL, Kittler B, Price W, Aguilar F (2015) Environmental implications of increased reliance of the EU on biomass from the Southeast US. ENV.B.1/ETU/2014/0043 Available at: http://www.aebiom.org/wpcontent/uploads/2016/08/DG-ENVI-study-imports-from-US-Final-report-July-2 016.pdf. Accessed 8 Jan 2020.

15. Birdlife, Greenpeace, EEB, Client Earth, FERN (2012) NGO brief sustain issues for solid biomass in electricity, heating and cooling. https://www.birdlife. org/sites/default/files/attachments/EU-Joint-NGO-briefing-biomasssustainability-energy-March2012.pdf. Accessed 8 Jan 2020.

16. Hammel D, Smith D (2013) Our forests aren't fuel. Retrieved from https:// www.dogwoodalliance.org/wp-content/uploads/2013/05/Enviva-MillinAhoskie-Dogwood-Report.pdf. Accessed 8 Jan 2020.

17. Larsen S, Bentsen NS, Stupak I (2019) Implementation of voluntary verification of sustainability for solid biomass - a case study from Denmark. Energy, Sustainability and Society 9(1):33. https://doi.org/10.1186/s13705019-0209-0.

18. Drax Biomass Collaborates With Atchafalaya Basinkeeper To Protect Louisiana's Valuable Wetlands. https://www.draxbiomass.com/press_release/ drax-biomass-collaborates-atchafalaya-basinkeeper-protect-louisianasvaluable-wetlands/. Accessed 3 July 2019.

19. Ofgem Biomass Sustainability. https://www.ofgem.gov.uk/environmentalprogrammes/ro/applicants/biomass-sustainability. Accessed 1 Mar 2019.

20. Report on sustainability criteria and an assessment framework for the use of woody biomass ('Rapport duurzaamheidscriteria en een afwegingskader voor de inzet van houtige stromen'): https://www.ovam.be/sites/default/ files/atoms/files/Rapport-duurzaamheids-afwegingskader-houtigestromenDEF.pdf. Accessed 1 Mar 2020.

21. Recommendations for the development of a Walloon Biomass-energy strategy. https://energie.wallonie.be/servlet/Repository/recommandationsstrategie-biomasse-energie-21-04-16.pdf?|D=43288. Accessed 1 Mar 2020.

22. Mansoor M, Stupak I, Smith T (2016) Chapter 17. Private regulation in the bioenergy sector. In: Bouthillier Y, Cowie A, Martin P, McLeod-Kilmurray H (eds). Law and Policy of Biofuels. Edward Elgar Publishing, pp 406-438.

23. Flinkman J, Sikkema R, Spelter H, Jonsson R (2018) Exploring the drivers of demand for non-industrial wood pellets for heating - an econometric inventory. Baltic Forestry 2018(1):86-98

24. Kristöfel C, Strasser C, Marawetz UB, Schmidt J, Schmid (2014). Analysis of woody biomass

25. Stupak I, Smith CT (2018) Feasibility of verifying sustainable forest management principles for secondary feedstock to produce wood pellets for co-generation of electricity in the Netherlands. IEA Bioenergy Task 43 TR2018:01. http:/task43.ieabioenergy.com/wp-content/uploads/2018/04/TR2 018-01.pdf. Accessed 8 Jan 2020.

26. RVO, 2019. Stimulation of sustainable energy production (SDE+). https:// english.rvo.nl/subsidies-programmes/sde. Accessed 1 Mar 2019.

27. European Commission (2018) Directive (EU) 2018/2001 of the European Parliament and of the Council of 11 December 2018 on the promotion of the use of energy from renewable sources. EN Official Journal of the European Union, L 328/82, 21.12.2018. https://eur-lex.europa.eu/legalcontent/EN/TXT/?uri=uriserv:OJ.L_.2018.328.01.0082.01.ENG .Accessed 8 Jan 2020.

28. Abt KL, Abt RC, Galik CS, Skog KE (2014) Effect of policies on pellet production and forests in the US south: a technical document supporting the forest service update of the 2010 RPA assessment. Gen. Tech. Rep. SRS202, Asheville, NC: U.S. Department of Agriculture Forest Service, Southern Research Station, 33 pp. http://www.treesearch.fs.fed.us/pubs/47281. Accessed 8 Jan 2020.

29. Costanza JK, Abt RC, McKerrow AJ, Collazo JA (2017) Bioenergy production and forest landscape change in the southeastern United States. GCB Bioenergy 9:924-939. https://doi.org/10.1111/gcbb.12386

30. Parish ES, Dale VH, Kline KL, Abt RC (2017) Reference scenarios for evaluating wood pellet production in the Southeastern United States. Wiley Interdisciplinary Reviews: Energy and Environment. https://doi.org/10.1002/ wene. 259

31. Duden AS, Verweij PA, Junginger HM, Abt RC, Henderson JD, Dale VH et al (2017) Modeling the impacts of wood pellet demand on forest dynamics in southeastern United States. Biofuels, Bioproducts and Biorefining. https:// doi.org/10.1002/bbb.1803

32. Birdsey R, Duffy P, Smyth C, Kurz WA, Dugan AJ, Houghton R (2018) Climate, economic, and environmental impacts of producing wood for bioenergy. Environmental Research Letters 13(5):050201. https://doi.org/10. 1088/1748-9326/aab9d5

33. Galik CS, Abt RC (2016) Sustainability guidelines and forest market response: an assessment of European Union pellet demand in the southeastern United States. GCB Bioenergy 8(3):658-669. https://doi.org/ $10.1111 / g c b b .12273$

34. Sikkema R, Junginger M, van Dam J, Stegeman G, Durrant D, Faaij A (2014) Legal harvesting, sustainable sourcing and cascaded use of wood for bioenergy: their coverage through existing certification frameworks for sustainable forest management. Forests 5(9):2163-2211. https://doi.org/10. 3390/f5092163

35. Fritsche UR, Werner $\mathrm{H}$, Iriarte L (2014) Possibilities of sustainable woody energy trade and impacts on developing countries. International Institute for Sustainability Analysis and Strategy (IINAS). http://iinas.org/tl_files/iinas/ downloads/IINAS_2014_Sust_Woody_Bioenergy_summary_report_GIZ.pdf. Accessed 8 Jan 2020.

36. Goovaerts $L$ et al. (2013) Examining sustainability certification of bioenergy. Subreport (Task 1) of the study 'Monitoring Sustainability Certification of Bioenergy', joint study involving IEA Bioenergy Task 40, Task 43 and Task 38. Available at: http://bioenergytrade.org/downloads/iea-sust-cert-task-1-final2 013.pdf. Accessed Feb 2013.

37. Kittler BA, Price W, McDow W, Larson B (2012) Pathways to sustainability: an evaluation of forestry programs to meet European biomass supply chain requirements. Environmental Defense Fund and Pinchot Institute for Conservation. https:/www.usendowment.org/pathways-to-sustainability-an- 
evaluation-of-forestry-programs-to-meet-european-biomass-supply-chainrequirements/. Accessed 8 Jan 2020.

38. Martikainen A, Van Dam J (2010) Evaluation report of different criteria for sustainability and certification of biomass and solid, liquid and gaseous biofuels-D 4.4. 1. EU Bionet III Solutionas for Biomass Fuel Market Barriers and Raw Material Availability—IEE/07/777/S12, 499477. Available at: https:/ www.vtt.fi/inf/julkaisut/muut/2010/D4-4-2-EUBIONETIII_Sustainability_ Different_criteria.pdf. Accessed 8 Jan 2020.

39. Scarlat N, Dallemand JF (2011) Recent developments of biofuels/bioenergy sustainability certification: a global overview. Energy Policy 39(3):1630-1646. https://doi.org/10.1016/j.enpol.2010.12.039

40. Thiffault E, Endres J, McCubbins JS, Junginger M, Lorente M, Fritsche $U$, Iriarte $L$ (2015) Sustainability of forest bioenergy feedstock supply chains: local, national and international policy perspectives. Biofuels, Bioproducts and Biorefining 9(3):283-292. https://doi.org/10.1002/bbb.1547

41. Van Dam J, Junginger M, Faaij A, Jürgens I, Best G, Fritsche U (2008) Overview of recent developments in sustainable biomass certification. Biomass and Bioenergy 32(8):749-780. https://doi.org/10.1016/j.biombioe.2008.01.018

42. Van Dam J, Junginger M, Faaij AP (2010) From the global efforts on certification of bioenergy towards an integrated approach based on sustainable land use planning. Renewable and Sustainable Energy Reviews 14(9):2445-2472. https://doi.org/10.1016/j.rser.2010.07.010

43. Vis MW, Vos J, Van den Berg D (2008) Sustainability criteria and certification systems for biomass production. Final report. Prepared for DG TRENEuropean Commission. BTG biomass technology group BV, Enschede, The Netherlands, https://www.compete-bioafrica.net/sustainability/sustainability_ criteria_and_certification_systems.pdf. Accessed 8 Jan 2020.

44. 33 U.S.C. \$1251 et seq. (1972) U.S. Federal Clean Water Act. https://www.epa. gov/sites/production/files/2017-08/documents/federal-water-pollutioncontrol-act-508full.pdf. Accessed 1 Mar 2019.

45. 16 U.S.C. § 1531 et seq. U.S. Federal Endangered Species Act. https://www. fws.gov/endangered/esa-library/pdf/ESAall.pdf. Accessed 8 Jan 2020.

46. UK Timber Procurement Policy. https:/uwww.gov.uk/guidance/timber-procurementpolicy-tpp-prove-legality-and-sustainablity. Accessed 1 Mar 2019.

47. Wear DN, Greis JG (2013) The Southern Forest Futures Project: Technical Report Gen. Tech. Pre. SRS-178, United States Department of Agriculture, Forest Service, Research and Development, Southern Research Station, Asheville, NC, 533 pp.

48. Forisk Consulting (2013) Update and Context for U.S. Wood Bioenergy Markets. Athens. http://www.theusipa.org/Documents/NAFO-US_Bioenergy_ Markets-FINAL-201306261.PDF

49. NatureServe Database. http://www.natureserve.org/. Accessed 1 Mar 2019.

50. Natural Heritage Datasets. https//catalog.data.gov/dataset?metadata_type= geospatial\&_metadata_type_limit=0\&q=Natural\%20Heritage. Accessed 1 Mar 2019

51. FSC US National Risk Assessment. https://us.fsc.org/en-us/certification/ controlled-wood/fsc-us-controlled-wood-national-risk-assessment-us-nra. Accessed 5 Nov 2019.

52. Regulation (EU) No $995 / 2010$ of the European Parliament and of the Council of 20 October 2010 laying down the obligations of operators who place timber and timber products on the market Text with EEA relevance https://eur-lex.europa.eu/legal-content/EN/TXT/?uri=CELEX\%3A32010R0995. Accessed 8 Jan 2020.

53. Forisk Consulting (2015) Q2 2015 Forisk Research Quarterly. https://forisk. com/blog/2015/06/09/wood-bioenergy-update/. Accessed 8 Jan 2020.

54. Forisk Consulting (2015) http://www.forisk.com/blog/2015/10/23/nibblingon-a-chicken-or-nibbling-on-an-elephant-another-example-of-incompleteand-misleading-analysis-of-us-forest-sustainability-and-wood-bioenergymarkets/. Accessed 1 Mar 2019.

55. Forisk Consulting (2015) How can global demand for wood pellets affect local timber markets in the U.S. South? May 2015.

56. RISI (2015) North American woodfibre and biomass markets. 8 pp.

57. RISI (2015) North American Bioenergy Forecast - 5-Year.

58. Stewart P (2014) How much of a manufacturing facility's wood supply should be under supply agreement? http://blog.forest2market.com/howmuch-wood-supply-do-i-need-under-agreement. Accessed 8 Jan 2020.

\section{Publisher's Note}

Springer Nature remains neutral with regard to jurisdictional claims in published maps and institutional affiliations.

\section{Ready to submit your research? Choose BMC and benefit from:}

- fast, convenient online submission

- thorough peer review by experienced researchers in your field

- rapid publication on acceptance

- support for research data, including large and complex data types

- gold Open Access which fosters wider collaboration and increased citations

- maximum visibility for your research: over $100 \mathrm{M}$ website views per year

At BMC, research is always in progress.

Learn more biomedcentral.com/submissions 